\title{
HUSSERL'S MODERATE RATIONALISM AND THE QUESTION OF EVIDENCE
}

\section{WITOLD PŁOTKA}

$\mathrm{PhD}$ in Philosophy, Dr. habil., Associate Professor.

Cardinal Stefan Wyszynski University in Warsaw, Institute of Philosophy.

01-815 Warsaw, Poland.

E-mail: witoldplotka@gmail.com; w.plotka@uksw.edu.pl

This article is an attempt to present Husserl's phenomenology as a moderate form of rationalism. By 'moderate rationalism' is understood, first, a theory that does not exclude the problem of irrationality, and that comprehends the rational as a correlate of the irrational. Second, it is a theory that performs its analyses by adopting the thesis that evidence can be achieved at many levels and grades. Here perfect evidence can also appear as imperfect. Yet this imperfect evidence (as an equivalent to unreason) can be a subject of evidential inquiry (as an equivalent to reason). The argument is that moderate rationalism is connected with the transcendental character of phenomenology and leads to the perennial reconsideration of the question of evidence (Evidenz). A basic claim is that irrationality is to be understood in terms of possible vague levels and grades of evidence. By developing 'moderate rationalism' thus understood, one is interested in understanding reason, that is, in the question of the essence of reason in its correlation with unreason. Here, moderate rationalism is directly interested not in rational arguments, but in 'elucidation' of reason. It is argued that phenomenology of reason also investigates 'irrational evidence,' for example, background evidence, evidence with respect to others, as well as all forms of fallible evidence. Therefore, the main question of moderate rationalism is Husserl's question of evidence.

Key words: Phenomenology, theory of knowledge, critique of reason, unreason, evidence, rationalism, Husserl.

(C) WITOLD PŁOTKA, 2019 


\section{УМЕРЕННЫЙ РАЦИОНАЛИЗМ ГУССЕРЛЯ И ВОПРОС ОБ ОЧЕВИДНОСТИ}

ВИТОЛЬД ПЛОТКА

$\mathrm{PhD}$, доктор философии, профессор.

Варшавский университет, Институт философии.

01-815 Варшава, Польша.

E-mail: witoldplotka@gmail.com;w.plotka@uksw.edu.pl

Данная статья является попыткой представить феноменологию Гуссерля как умеренный рационализм. Под «умеренным рационализмом» понимается, во-первых, теория, не исключающая проблемы иррациональности и понимающая рациональное как коррелят иррационального. Во-вторых, это теория, которая осуществляет свой анализ, исходя из тезиса о том, что очевидности могут быть представлены на многих уровнях и ступенях. Здесь совершенная очевидность вполне может оказаться несовершенной. Однако это несовершенная очевидность (как эквивалент неразумия) может стать предметом очевидного исследования (как эквивалент разума). Аргументация состоит в том, что умеренный рационализм связан с трансцендентальным характером феноменологии и ведет к постоянному пересмотру вопроса об очевидности (Evidenz). Основное утверждение состоит в том, что иррациональность следует понимать в терминах возможных неопределенных уровней и степеней очевидности. Развивая таким образом «умеренный рационализм», мы заинтересованы в понимании разума, то есть в вопросе о сущности разума в его соотношении с неразумием. Здесь умеренный рационализм непосредственно заинтересован не в рациональных аргументах, а в «прояснении» разума. Утверждается, что феноменология разума также исследует «иррациональные очевидности», например, фоновые очевидности, очевидности в отношении других, а также все формы ошибочных очевидностей. Поэтому главным вопросом умеренного рационализма является Гуссерлевский вопрос об очевидности.

Ключевые слова: Феноменология, теория познания, критика разума, неразумие, очевидность, рационализм, Гуссерль.

\section{INTRODUCTION}

For many scholars Edmund Husserl's phenomenology is inseparable from its rationalist claims ${ }^{1}$. Husserl himself repeatedly calls his philosophy rationalism (Rationalismus) (Hua VII, 317; XXVII, 238-239; XXXV, 291, 361)². He understands his attempt, of course, as a new rationalism, as opposed to the old one. He identifies,

1 See, for instance, (Fink, 1966, 194 / 1981, 24; Merleau-Ponty, 1945, xvi / 2002, xxiv; Aguirre, 1972, 102; Funke, 1980, 33).

2 Subsequently, references to Husserliana (1950-) volumes will be abbreviated directly in the text followed by the volume (in Latin numerals) and page numbers (in Arabic numerals). For the list of quoted Husserliana, see References. 
however, this new rationalism as an Überrationalismus ${ }^{3}$. At the same time, he defines the main task of phenomenology as a struggle against the irrationalism (Irrationalismus) that he compares with mysticism and skepticism (Hua VI, 1, 90, 339; VII, 187; XXVII, 237-238; XXVIII, 202; XXIX, 103, 228). This sharp division between rationalism and irrationalism seems to be consistent with a popular interpretation of Husserl's philosophy as divided into two phases. In this regard, Husserl's Logische Untersuchungen is viewed as "a work of breakthrough" (Hua XVIII, 8), because it defines phenomenology as a descriptive philosophy. Husserl's later attempt (in Ideen I) to redefine phenomenology as transcendental philosophy and as a rigorous science marks a clear divide between realistic and idealistic approaches to phenomenology. This view was popularized by Max Scheler (1995) and Roman Ingarden (1975), for example. Additionally, the second phase of the development of Husserl's philosophy seems to present a formulation of his philosophy as the theory of reason tout court, since all transcendental philosophy is theory of reason (Hua II, 22). Husserl's next turn (in Die Krisis), towards the problem of the crisis of the European sciences, however, seems to mark another breakthrough, one that suggests his denial of the project of philosophy understood as a rigorous science. From the perspective of the question of rationality, it may also appear that this last breakthrough marks Husserl's denial of his earlier theory of reason. After all, the lifeworld seems to be irrational, at least when we compare it with the high standards of scientific (transcendental) rationality. One recalls Husserl's famous words from 1935 (1934?): „Philosophie als Wissenschaft, als ernstliche, strenge, ja apodiktisch strenge Wissenschaft - der Traum ist ausgeträumt" (Hua VI, 508).

In my opinion this popular view is an unjustified oversimplification. Also, the view that Husserl's late philosophy represents an anticipation of subsequent postmodern thought does not do justice to the entire complexity of Husserl's

3 As Husserl writes in a letter to Lucien Lévy-Bruhl from March, 11, 1935: „Vielleicht werden die vorbereiteten neuen Publikationen [...] einige Vorstellung davon geben, wie aussichtsvoll und konkret die Methode ist, durch die ich gegen den schwächlichen Mystizismus und Irrationalismus eine Art Überrationalismus begründen will, der den alten Rationalismus als unzulänglich überschreitet und doch seine innersten Intentionen rechtfertigt“" (Husserl, 1994b, 164).

4 David Carr translates the fragment as follows: "Philosophy as science, as serious, rigorous, indeed, apodictically rigorous science-the dream is over" (Husserl, 1970, 389). These words, however, have their context, which permits two divergent interpretations of them. On the one hand, Lübbe (1957/1958, 233), Hohl (1962, 78), and Landgrebe $(1963,187)$ propose to understand these words as Husserl's abandonment of the idea of philosophy as rigorous science, whereas, on the other hand, Spiegelberg (1994, 149, footnote 4), Gadamer $(1963,25)$, and Janssen (1970, xx-xxi, footnote 16, 142, footnote 8) claim that Husserl expresses only a diagnosis of his times, and this diagnosis should lead towards a renewal of the idea. 
development. Rather, I think that it is more accurate to speak of Husserl's reconsiderations of the theory of reason, and not of a series of breakthroughs. As a result, I want to suggest that one faces a kind of continuity within Husserl's philosophy. His considerations on reason start with the question of arithmetic. After all, mathematical beings are, generally speaking, beings of reason (Hua XII, 11, 442443; XXI, 219). On the one hand, then, by posing (in Philosophie der Arithmetik) the question of how a number is in general knowable (Hua XII, 13), Husserl considers the question of the limits of reason. On the other hand, we may say that the breakdown of rationality (as defined in Die Krisis) is, for Husserl, not a sign that rationality (in its true sense, that is, philosophy) is no longer possible (Hua VI, 14). Rather, it is a sign that the old rationality is in fact not a genuine rationality, and that its bankruptcy has finally been exposed. Thus the crisis makes evident for Husserl the need for the true form of rationality, for true philosophy, for transcendental phenomenology, that is, for a genuine theory of reason (Hua VII, 145). In other words, Husserl's entire philosophical enterprise is a perennial analysis of reason, where reason itself is a Kantian, that is, regulative, idea that organizes philosophical inquiries.

The theory that Husserl has to offer in this context is a correlative view of reason that is essentially connected with the irrational. Let me call this theory "moderate rationalism," since it brackets the thesis about "the unbounded range of objective reason” („die Schrankenlosigkeit der objektiven Vernunft“) (Hua XIX/1, 95). Moderate rationalism, however, has both theoretical and practical effects. In this article, I want to focus on theoretical effects, and, by doing so, to present some consequences of moderate rationalism in theory of knowledge. An examination of the development of Husserl's theory of knowledge shows how he redefines and broadens the narrow limits of rational claims to objectivity. Thus this article argues that, on account of the development of his phenomenology, Husserl's concept of reason and its position in the whole system of his philosophy is not a consistent construction. Rather, the concept undergoes substantial change during Husserl's reconsiderations of his project. Yet the development does not present a series of breakthroughs, but rather a widening of preliminary remarks.

In this regard, one clarification is necessary. The label 'moderate rationalism' was recently used in a different context by Berghofer (2018c). In his study which juxtaposes Husserl's empiricism with traditional rationalism, Berghofer (2018c, 541) provides a twofold exposition of 'moderate rationalism' which "allows that a priori justification can be fallible and empirically underminable" (Berghofer, 2018c, 541). So, for Berghofer (2018c, 560), Husserl's 'moderate rationalism' accepts that 
"[a] priori justification is fallible," and "[a] priori justification can be undermined by empirical evidence." The present study differs from Berghofer's exposition in two aspects: first, this study focuses rather on the concept of reason (e.g., understood as objective reason) than on epistemic justification; what follows, second, it adopts mainly a historical perspective since I argue here that Husserl's theory of reason does not present a series of breakthroughs, but rather a widening of preliminary remarks. Nonetheless, regarding more specified issues, the article develops Berghofer's first claim, i.e., the fallibility claim, and given this, it is argued that evidence can be essentially fallible 5 .

\section{PSYCHOLOGISM, OBJECTIVITY, AND REASON}

From the start, Husserl's view of reason was shaped by his altercation with psychologism. Indeed, his theory of reason as set forth in the Untersuchungen can be grasped as a background and as a tacit presupposition of his discussion with the nineteenth century thesis that "the theoretical discipline underlying the normative and practical or technological dimensions of logic is psychology" (Drummond, 2008, 172-173). One can argue that prior to the Untersuchungen Husserl accepted the thesis of psychologism, and for this reason Herbert Spiegelberg calls the period preceding the Untersuchungen 'pre-phenomenological.' This period, as Spiegelberg $(1994,70)$ emphasizes, "begins with an attempt to interpret mathematics by a descriptive psychology of the acts of mathematical thinking." Of course, in the Vorrede to Philosophie der Arthmetik Husserl demands a methodological priority of psychology while inquiring into the foundations of arithmetic (Hua XII, 5-6) . $^{6}$ Nonetheless, psychologism in mathematics leads towards relativism, and mutatis mutandis towards scepticism, because it conflates mathematical beings (ideal contents of numbers) with psychological processes (real acts of counting). The 'prephenomenological' period ends with the publication of the Untersuchungen, in the Prolegomena to which Husserl presents a crucial critique of psychologism in mathematics and in logic. Psychologism can, of course, assume many forms (e.g., de Boer, 1978, 116-117). It is safe to say, however, that "[i]n the Prolegomena, Husserl

\footnotetext{
As Berghofer $(2018 \mathrm{c}, 555)$ puts it, "[t]he point is that moderate rationalists are not committed to the claim that infallibility is a necessary feature of the a priori."

6 Even this clear demand is a subject of discussion of scholars who claim that it is possible to interpret Husserl's Philosophie der Arithmetik in an anti-psychologistic manner. Cf. (Hopkins, 2006).
} 
gives the most wide-ranging and painstaking critique of psychologism that is to be found in the philosophical literature" (Mohanty, 2008, 65). In the Prolegomena zur reinen Logik Husserl presents a number of arguments against psychologism, but all of them collectively aim to show that psychologism is both practically and theoretically impossible. The basic thread of these arguments runs like this: Psychologism claims to be a true, that is, objective, theory; but it asserts that every theory is relative to a particular process of thought, and that each process is subjective; therefore psychologism cannot justify its claim as true, and it is simply impossible ${ }^{7}$. Husserl provides at least three clear comments to the effect that theory of reason should be comprehended as a background of his refutation of psychologism.

First, while commenting on the purpose of the first volume of the Untersuchungen, Husserl writes in „Bericht über deutsche Schriften zur Logik in den Jahren 1885-99“ (1903): „Ich habe dort [...] auch zu zeigen versucht, daß die Idee des normalen, geistig gesunden Menschen die Idee der Vernunft schon voraussetzt, also gar nicht geeignet ist, sie, bzw. die Sphäre des Logischen, allererst zu begrenzen“" (Hua XXII, 208). In the Prolegomena, then, Husserl presents a 'normal' idea of reason. The idea is defined with respect to a 'normal,' that is, mentally healthy, human being. Hence ,normality' also involves a certain understanding of reason. Second, in the Vorwort zur zweiten Auflage (1920) to the Sechste Untersuchung, Husserl writes that he offers in the Untersuchungen: „die erste radikale Überwindung des Psychologismus in der Theorie der Vernunft" (Hua XIX/2, 534). Accordingly, in the Untersuchungen, Husserl discusses theory of reason as restricted to formal logic. Third, at the very beginning of the lectures on phenomenological psychology (from 1925) Husserl combines the purpose of the Untersuchungen with his research on the theory of reason (Hua IX, 42). Hence the question: How does Husserl's altercation with psychologism ground his theory of reason?

According to the diagnosis formulated in the Prolegomena, psychologism denies the objectivity of science, because it grounds the meanings of scientific statements in subjective acts of expression, and it confuses objective logical laws with subjective psychological laws. As a consequence, the logical laws that govern

Husserl discusses the empirical forms of psychologism, claiming that they are forms of relativism and that they involve inconsistencies. In psychologism, he asserts, one accepts "possible changes in the laws of thought" („die Möglichkeit der Änder ung der Denkgesetze“) (Hua XVIII, 143). If these changes are possible, however, then psychologism refutes its own scientific character and therefore it denies the objectivity of its own thesis. To put it differently, if psychologism claims to be a science, it must be objective, that is, regardless of any possible changes. 
contents of thoughts are reduced to the psychological laws that govern acts of thinking. Science in general and logic in particular (not to mention mathematics, which is essentially a branch of $\left.\operatorname{logic}^{8}\right)$, however, are domains of reason. For Husserl, the term 'reason' is ambiguous, because

Verstand als psychisches Vermögen, d.i. als Titel für eine Klasse psychischer Erlebnisse und Erlebnisdispositionen ist ein Faktum der Natur und zu unterscheiden vom Verstand als einer Idee, d.i. einem Titel für gewisse Arten der Normalität, und zwar der nicht-empirischen Normalität. (Hua XXX, 16)

Therefore psychologism is indirectly related to the problem of reason, because it confuses two different meanings of reason: first as a psychic power, and second as an idea that designates a non-empirical normalization. In the Prolegomena, reason is understood as an objective field of ideal laws, which Husserl grasps as 'forms of knowledge' (,Formen der Erkenntnis') (Hua XVIII, 121). But such forms are merely instantiated in particular acts of thinking; they are not generated by the acts. As suggested above, the 'normal' human being participates in these 'forms' by arguing logically, but, at the same time, she overcomes her particular structures. Furthermore, everyone should argue in such a way, otherwise she would be 'abnormal,' thus irrational, and, to quote Husserl, simply 'mad' (Hua XVIII, 104-105).

For Husserl, at least in the Prolegomena, the fact of science is unquestionable. For him, this means that science is a 'normal,' and a rational, discipline. On the other hand, reason is here a domain of objectivity. Originally, in the Untersuchungen, Husserl asserted that a person can repeatedly utter an expression in infinitum without altering its meaning. Consequently, the meaning is supposed to be strictly identical in the sense of a species. Thus far, then, the formulation of the thesis in the Untersuchungen about "the unbounded range of objective reason" („die Schrankenlosigkeit der objektiven Vernunft") (Hua XIX/1, 95) should not be surprising. In the Untersuchungen, that is, Husserl introduces the concept of reason as a norm: here the "rational" designates the "normal" (Hua XVIII, 104$105)^{9}$. Also, 'normality' is supposed to be accepted by any rational individual. Hence,

8 For discussion, see (Hartimo, 2010).

9 In the Logische Untersuchungen, Husserl presents the following proposition: „Wir nennen den einen Vernünftigen, dem wir die habituelle Disposition zutrauen, ,bei normaler Denkverfassung 'in seinem Kreise richtig zu urteilen. Wer die habituelle Befähigung besitzt, in normaler Denkverfassung zum mindesten das ,Selbstverständliche,' , auf der Hand Liegende' nicht zu verfehlen, gilt uns in dem hier fraglichen Sinne als ,zurechnungsfähig“" (Hua XVIII, 98). 
following Husserl, one is supposed to accept the concept of reason as an ideal and/ or unchangeable system of laws, one that justifies 'truths in themselves.'

\section{STRONG RATIONALISM AND PERFECT EVIDENCE}

The phenomenon of reason, so far, is multidimensional. In working out the relativistic and skeptical consequences of psychologism, Husserl places a special emphasis on the concept of objective reason. According to Adorno, Husserl's theory of reason was shaped by the mathematical character of phenomenology. In this respect, phenomenology seems to be similar to classical rationalism, or to absolute science ${ }^{10}$. Although Adorno's interpretation must be questioned, it is consistent with Husserl's striving for perfect evidence. This objective view of reason, with its claim to perfect evidence, is what I shall call 'strong rationalism.' Inasmuch as psychologism presents reason as a mere matter of fact, and as a quid facti, Husserl's position can be described as 'strong rationalism.' For he uses the concept of objective reason as a domain of ideas and as a quid juris. Also, he takes this position to fulfil stringent requirements for what reason has to be in the face of the danger of psychologism, that is, in the face of the risk of scepticism. In a word, he introduces the concept of ideal reason in order to avoid the psychological consequences of logic. In the Prolegomena, Husserl shows that logical psychologism fails to make the defining distinction of pure logic between the real act of judging and the ideal content of judgment. As a result, failure to distinguish between real cognitive acts and ideal cognitive contents transforms logic and epistemology (and mathematics) into branches of psychology. Only by introducing a distinct understanding of reason one can completely refute psychologism. To do so, Husserl has to establish a 'normal' notion of reason, according to which reason is not a subjective property of thinking, but rather an ideal structure that makes thoughts clear. Here Husserl establishes a connection between reason and clarity, or-using his terminus technicus-evidence. It must be emphasized that the correlation of reason and evidence (thus: clarity) is a leitmotif of his entire philosophy.

In the second volume of the Untersuchungen, Husserl introduces the concepts of empty intentions and fulfilling intuitions to express the fact that reason is not

10 "From his mathematical beginnings to the very end he was concerned only with the justification of vérités éternelles, and for the passing phenomena he held all the contempt of the classical rationalist" (Adorno, 1940, 6-7). Cf. also (Adorno, 2003, 13). 
a definitive feature of cognition, but rather that human being becomes rational, and thus that reason is, so-to-speak, in statu nascendi. The doctrine of intentions and fulfillments serves in phenomenology of knowledge as a basis for understanding a difference between symbolic and intuitive thinking. Symbolic thinking, namely, operates on non-intuitive elements that lack immediacy of intuition (Hua XIX/2, $534)^{11}$. With regard to this thesis, it must be emphasized that the process of fulfilling empty intentions is a strictly rational process. In a word, reason strives towards a complete fulfillment, which represents an ideal of truth. Husserl describes the presence of an object in intuition in terms of evidence (Evidenz), and he maintains that perfect, that is, adequately fulfilled, evidence is a correlate of $\operatorname{truth}^{12}$. Although one must not forget that evidence is matter of degrees and levels, according to strong rationalism, only "the final ideal of perfection, the ideal of adequate perception, of the complete self-manifestation of the object” („letzten Vollkommenheitsideal: dem der adäquaten Wahrnehmung, der vollen Selbsterscheinung des Gegenstandes") and "this most perfect synthesis of fulfillment” („vollkommensten Erfüllungssynthesis“) (Hua XIX/2, 651) is worth pursuing. Especially Husserl's Die Idee der Phänomenologie repeats the demand for perfect evidence. As he argues, our true knowledge concerns immanent necessities that are beyond any possible doubt (Hua II, 33); everything that is not immanent in this pregnant sense of immediate evidence is transcendent (Hua II, 35), that is, it is not given in "adequate self-givenness" (adäquate Selbstgegebenheit) (Hua II, 59). According to radical rationalism, one is interested in "the sphere of pure evidence" (die Sphäre der reinen Evidenz), that is, evidence in "a strict sense" (strengen Sinn) that "excludes" (ausschließt) "mediate evidence" (mittelbare Evidenz) (Hua II, 61). Therefore, despite a number of possible degrees and levels of evidence, every epistemically fundamental piece of knowledge requires perfect evidence. In a word, evidence has justificatory force (Berghofer, 2019, 103).

Unfortunately, a thorough analysis of this aspect of phenomenology of knowledge would exceed the limits of this study ${ }^{13}$. Let us assume, however, that Husserl's philosophy of the period of the Untersuchungen is dominated by a static

11 On the problem of intuition, symbolic thinking, and empty intentions in Husserl, see (Crowell, 2007;Byrne, 2017).

12 "For Husserl, evidence consists of experiences or more precisely of originary presentive intuition" (Berghofer, 2018c, 556). See also (Berghofer, 2019, 98-99, 101-109).

13 On Husserl's theory of knowledge, see, for instance, (Rinofner-Kreidl, 2003, 1-124; Lerner, 2004; Heffernan, 1998; 2009; Hopp, 2009; 2011; Berghofer, 2018a, 2019; Płotka, 2016). 
view of reason. From its very beginnings in the Untersuchungen, Husserl has described phenomenology as a science that points towards the essences of 'the things themselves.' Although he changes the concept of essence, he does not modify the concept of phenomenology itself as a descriptive and eidetic science. Whereas in the Untersuchungen (with the possible exception of the Sechste Untersuchung) he sees essence as an ideal, non-temporal object, he clearly criticizes such a position in his later works. One should recall that originally Husserl asserts that a person can repeatedly utter an expression in infinitum without altering its meaning. As a result, the meaning is strictly identical in the sense of a species. Later, however, in a letter to Roman Ingarden, Husserl articulates his position that the repetitiveness of utterances should not be confused with an ideal, non-temporal concept of meaning ${ }^{14}$. Hence we can speak of the immanent enlargement of a phenomenological concept of reason as well. No doubt, after Husserl's departure from what may be interpreted as 'static' Platonism (and was criticized by Neokantians $\mathrm{s}^{15}$ ), essence assumes a temporal dimension. In other words, essences can be determined by activities that alter the primordial, temporal field of essences. For this reason, Husserl develops the method of eidetic variation, that is, because essences have a temporal structure, they cannot be given once and for all, but rather must be constituted in a series of variants. This, however, suggests a reconsideration of the concept of objective reason, and its reinterpretation in the light of the thesis about unreason (Unvernunft).

\section{A CORRELATION OF REASON AND UNREASON}

The foregoing observations suggest that Husserl's phenomenology of reason is incomplete without a phenomenology of unreason (Unvernunft $)^{16}$. In fact, Husserl characterizes unreason (Unvernunft) as "negatives Gegenstück der Vernunft" (Hua

14 „Der Fehler lag vor allem in der Fassung des ,Sinnes` u. ,Satzes, ‘ bei Urtheilserlebnissen des prädikativen Urtheilssatzes u. Sinnes, als We se n, oder als ,Ideen' im Sinne von Wesen (Species). Die Unabhängigkeit des Seins eines Satzes von dem zufälligen Urtheil u. Urtheilenden besagt noch nicht, daß das ideal-Identische ein Specifisches ist.“ (Husserl, 1994a, 182).

15 Cf. (Natorp, 1917/1918, 224-246; Lembeck, 2003; Holzey, 2010; Staiti, 2013).

16 Husserl also claims that he does the phenomenology of unreason, for example, in the lecture series Grundprobleme der Ethik und Wertlehre (Hua XXVIII, 205), in Ideen I (Hua III/1, 127, 196, 249), in Phänomenologie und Psychologie (Hua XXV, 100, 115), in the article „Phänomenologie und Erkenntnistheorie“ (Hua XXV, 148, 197), in Die Pariser Vorträge (Hua I, 22), or while working on Die Krisis (Hua XXIX, 31, 332), as well as while inquiring into Grenzprobleme (Hua XLII, 441). In addition, in Cartesianische Meditationen Husserl identifies 'unreason' as „ein Universalthema der Phänomenologie“ (Hua I, 91). 
III/1, 333) and as "der negative Modus der Vernunft" (Hua XXIX, 7). In this sense, unreason appears in his phenomenology as a correlate of reason. Also, again in his phenomenology, irrationality emerges as a correlate of rationality. Although in the Untersuchungen Husserl formulates the thesis about the unbounded range of objective reason (which suggests that only reason is worth pursuing ${ }^{17}$ ), it is clear that in the long term reason cannot be properly described without posing the question about unreason. It is especially clear, for example, in Text Nr. 31 (1930), published in the recent Husserliana volume Grenzprobleme der Phänomenologie, where Husserl calls reason and unreason correlates (Korrelate) (Hua XLII, 441). This means, however, that there is no reason without unreason, and vice versa. Also, in the essay „Über die gegenwärtige Aufgabe der Philosophie“ (1934), Husserl sketches a metaphorical picture of reason surrounded by 'the spheres of irrationality'. $\mathrm{He}$ writes: „Glaubt man Grenzen der Vernunft feststellen zu können mit umgebenden Sphären der Irrationalität, so ist doch das vermeinte Irrationale rationales Thema und hat seinen Anteil an der Rationalität" (Hua XXVII, 206). Thus unreason appears as unreason only from the perspective of reason. But it cannot be ignored. Therefore it must be the subject matter of phenomenological inquiry.

Thus far, a phenomenological question about reason has led to the reconsideration of Husserl's philosophical project as sketched in the Untesuchungen. Now it turns out that, in opposition to the optimistic thesis about the unbounded range of objective reason, phenomenology involves "a thematization of something strange, alien to what is already a part of us" (Dodd, 2004, 70). In a word, phenomenology also thematizes unreason as a subject of rational inquiry. Indeed, one can argue that phenomenology is based on the view of 'a fundamental stratification' of 'the life of the logos.' Following the applicable suggestions from Husserl's Analysen zur passiven Synthesis, 'das Leben des Logos' may be distinguished into „Passivität und Rezeptivität,“ on the one hand, and „spontane Aktivität des Ich“ (Hua XI, 64), on the other hand. In Cartesianische Meditationen, the former is connected with 'irrationality' (Hua I, 114), and the latter with 'rationality' (Hua I, 108). At this most rudimentary level of inquiries, then, to ask about reason means to refer to the essential correlation between rationality and irrationality. Irrationality, however, is an operative concept; it hardly denotes a separate and hypostatic being. As such, the

17 Following Ram Adhar Mall, according to whom in Husserl's phenolmenology “[i]t is a reason which shows itself as a task and is clearly seen as 'lived' as such" (Mall, 1973, 115). 
concept enables one to think about a complex structure of reason which still remains, to quote Husserl's Krisis, the „Rätsel aller Rätsel“ (Hua VI, 12).

Husserl also seems to use the operative concept of the correlation of reason and unreason in the field of phenomenological psychology. It is well known that for Husserl psychology aims to grasp the essence of rational thinking (Hua IX, 6). By introducing the element of unreason and irrationality, psychology of reason can grasp thinking in terms of a horizon. The concept of horizon is structurally connected with the notion of intentionality, which is one of the most widely discussed and deeply studied concepts in the literature on Husserlian phenomenology ${ }^{18}$. For present purposes, it is enough to note that the concept of intentionality expresses the ability of consciousness to be directed towards something. Husserl's notion of reason is virtually defined by intentionality (Hua XXXIX, 171). For, if one is directed towards something, then one grasps something rationally. But this something is also always already surrounded by other somethings. Therefore, from the viewpoint of logic, each proposition implies prejudgments. Hence, in phenomenology, "no single, isolated cognition could have a character of absolute justification" (Landgrebe, 1963, 169). Each and every human cognition is continuously surrounded by its horizons and by "a hidden intentionality” (,verborgene Intentionalität") (Hua XVII, 366). Because of this, particular intentions point to other intentions, and so on. On the other hand, horizons themselves are not empty. Rather, they present possibilities of fulfillment. As Husserl strongly emphasizes even with respect to appearances of things:

Mit andern Worten, alles eigentlich Erscheinende ist nur dadurch Dingerscheinendes, daß es umflochten und durchsetzt ist von einem intentionalen Leerhorizont, daß es umgeben ist von einem Hof erscheinungsmäßiger Leere. Es ist eine Leere, die nicht ein Nichts ist, sondern eine auszufüllende Leere, es ist eine bestimmbare Unbestimmtheit. (Hua XI, 6)

Hence the concept of horizon indicates that every intention presupposes another, known or unknown, intention, introducing the possibility of irrationality into phenomenological-psychological investigations. According to Husserl, then, human cognition is accompanied by an “empty horizon” („Leerhorizont“) (Hua IX, 181) that co-determines the activity of reason. At this point, the phenomenological concept of horizon applies to the correlation between reason and unreason. Each thing known in a rational way necessarily presupposes an unknown horizon.

18 See, for instance, (Mohanty, 1971; Dreyfus, 1984; Sokolowski, 1987; Drummond, 1990; Gallagher \& Zahavi, 2008, 116-126). 
Regardless of how rational the known is, it is possible that the unknown encompasses unreason. Finally, on an epistemological level, one can say that unreason opens up for phenomenology the question of imperfect evidence.

\section{MODERATE RATIONALISM AND IMPERFECT EVIDENCE}

By reconsidering the phenomenological theory of reason, Husserl establishes a very important feature of phenomenology as a genuine theory of reason, namely, it always involves a reflection on its own meaning, that is, self-criticism. In the lectures on First Philosophy, Husserl considers the problem of the beginning in phenomenology ${ }^{19}$. He wants to establish how to begin investigations without adopting a naïve attitude. He concludes that every definitive justification is based on an assumption of 'objectivity,' and thus an assumption of the ideality of essences. He suggests that one has to accept this as inevitable, but he also points out that it is possible to achieve 'a reflective higher level' in investigations:

Jedenfalls gliedert sich die ,Phänomenologie' des reinen ego 1) in eine naiv-gerade Phänomenologie;2) eine reflexive höherer Stufe: als eine Theorie und Kritik der phänomenologischen Vernunft (Kritik des phänomenologisierenden Ich) oder der phänomenologischen Methode oder eine Kritik der phänomenologischen Evidenz. Es ist einzusehen, daß hiermit alle radikale Erkenntnistheorie erschöpft ist. (Hua VIII, 478)

These observations suggest, first of all, that the role of method in first philosophy can be understood as both naïve and critical at the same time. Secondly, if an initial naïveté is necessary, and even essential, for the phenomenological method, then it is possible to understand objectivity and objective reason only as a preliminary, but not as a definitive, description of reason. But what does it mean to say that the critique of method leads towards "a reflective higher level?"

Here one is led to the conclusion that phenomenological reflectionunderstood as a specific praxis of reason-involves a striving towards clarity and evidence, and that in a certain sense it is equivalent to the exercise of reason and rationality itself. Thus phenomenology becomes a „Theorie und Kritik der phänomenologischen Vernunft“"(Hua VIII, 478). More importantly, it becomes a critique of evidence. As a result, phenomenological reflection emerges as a rational activity tout court, for it brings evidence itself to evidence. It does not, however,

19 On the problem of the beginning of phenomenology, see, e.g., (Płotka, 2012; 2018). 
establish a naïve and perfect evidence of objective reason. Rather, it adopts the correlation thesis about reason und unreason. In doing phenomenology in this way, one abandons high requirements of strong rationalism, and starts doing moderate rationalism. By 'moderate rationalism' is understood a theory that performs its analyses by adopting the thesis that evidence can be achieved at many levels and grades. Here perfect evidence can also appear as imperfect (Heffernan, 2009). Yet this imperfect evidence (as an equivalent to unreason) can be a subject of evidential inquiry (as an equivalent to reason).

It is obvious that, for Husserl, 'the power of reason' makes 'self-critique' possible and, consequently, allows for 'critical corrections' as well. The critique is made possible by reason understood in a 'higher sense' or 'higher level' (höherer Stufe): precisely as the process of rational inquiry, that is, that inquiry which is directed towards evidence and intuition (Hua XXIX, 7-8). Therefore the radicalism of the phenomenological method, understood as the rational method, lies in its inquiry into the foundations of rationality ${ }^{20}$. By posing the question of objective reason (in the Untersuchungen), Husserl establishes a necessary point of departure for further investigations and, in consequence, for defining essences in terms of a series of variations that constitute horizons of eide. The later Husserl would regard the objective approach towards reason and evidence as naïve, because this theory of reason and knowledge is constructed 'from the top down' (von oben her). A genuine theory of reason, on the other hand, should be critical, which results in a plan to analyze reason as reason "from the bottom up" (von unten) (Hua XVII, 169; Hua $\mathrm{XXXV}, 274)^{21}$. Now one does not want to explain how reason becomes objective reason by formulating arguments that justify this thesis (because one runs into the problem of a petitio principii ${ }^{22}$ ). Rather, one is interested in understanding reason, that is, in the question of the essence of reason in its correlation with unreason. Moderate rationalism is directly interested not in rational arguments, but in 'elucidation' of reason. The subject of phenomenological description in the field of moderate

20 „Radikal sein heißt, zu den letzten Wurzeln herabsteigen, nämlich sie selbst zu sehen und prinzipiell alles Denken nur aus solchem Selbstgegebenen zu schöpfen, nach Einzelheiten und nach Prinzipien selbst" (Hua XXXV, 288).

21 „Habe ich es mir zur Lebensaufgabe gemacht eine Philosophie, von unten` mindestens für mich, zu meiner (s eh r schwer zu gewinnenden!) Befriedigung zu begründen, so strebe ich doch unablässig von dem ,Unten` hinauf in die Höhen" (Husserl, 1994a, 160) (Letter to Hocking, July, 7, 1912).

22 Cf. (Hua II, 39; Husserl, 2001, 151-152). 
rationalism are all the different varieties of reason and evidence ${ }^{23}$, and thus not only the type of reason and evidence that fulfills the highest requirements of the most rigorous theory of reason and evidence (as presented in the Untersuchungen). Hence phenomenology of reason also investigates 'irrational evidence' (sit venia verbo), for example, background evidence, evidence with respect to others, as well as all forms of fallible evidence ${ }^{24}$. There are many forms of ,Evidenz, and one has to describe all the forms, levels, and elements of the acts of rational knowing, that is, the acts of intentional presentation of an object, in a certain way. Therefore one also has to ask about an unclear and vague ,Evidenz.' After all, „Was ist das, Evidenz?" (Hua XXIV, $154)$ is the main question of phenomenology of reason. At the end, let me add that this reading of Husserl's moderate rationalism seems to correspond with Berghofer's view of a moderate foundationalism. In his recent paper, "Why Husserl is a moderate foundationalist," Berghofer (2018b, 13) argues-following, e.g., Beyer, Drummond, Føllesdal, and Zahavi-that Husserl advocates moderate foundationalism since he claims, among others, that intuition is a source of immediate justification, intuition is the ultimate source of justification, yet intuition is fallible, and evidence can be shattered by other evidence. After all, given that ,Evidenz' is the proper object for phenomenological descriptions, and that one for of evidence can be corrected, it is clear the evidence can be shattered by other evidence.

\section{CONCLUSION}

Husserl develops his philosophy as the new rationalism as opposed to the old one. One should understand the difference between the two as a radicalization

23 „Was andrerseits aber fehlt, ist eine systematische Charakteristik der sämtlichen verschiedenen Evidenzarten und der Rechtsgrenzen, die sie den entsprechenden Erkenntnisakten stecken, desgleichen eine systematische Untersuchung der im Bedeutungsgehalt dieser Akte liegenden Bedingungen der Möglichkeit der Evidenz, also eine vollständige noetische Axiomenlehre" (Hua XXIV, 138).

24 „Da hier überall bei den Fragen, wie diese oder jene Arten von Erkenntnissen (von individuellen oder generellen, realen und idealen, kategorialen und materialen, von unmittelbaren oder mittelbaren etc.) ,möglich sind,' die Wirklichkeit so gearteter Erkenntnis nicht in dem Sinn verwendet werden darf, dass von dem Wirklichsein der in ihnen gesetzten Gegenständlichkeiten Gebrauch gemacht würde, so haben alle solchen Fragen von vornherein keinen anderen Inhalt als den der Aufklärung des Sinnes der gegenständlichen Bedeutung der Erkenntnis bzw. des Sinnes der objektiven Triftigkeit der so genannten ,geltenden, echten Erkenntnis“ (Husserl 2005, 99; cf. also 5, 42; Hua XXXV, 35). Husserl claims: „Angenommen, wir sind zum Verständnis jener Korrelation von Bewußtsein und Gegenstand gekommen, die jedes, auch das traumende, halluzinierend irrende Bewußtsein betrifft, und wir fragen nun, wie wir zu der Existenz irgendeines Gegenstands an sich kommen können, so stehen wir vor dem Problem der Eviden z, oder, was dasselbe ist, dem Problem der Gegebenheit“"(Hua XXIV, 154-155). 
of questioning about the traditional view of objective reason. As a consequence, the old rationalism is connected with the concept of strong rationalism, whereas the new was defined above as the moderate rationalism that questions the concept of objective reason. I have claimed that Husserl's way from the old rationalism to the new can be understood as a series of reconsiderations of the concept of reason in general. In conclusion, I would like to advance the hypothesis that Husserl's reconsiderations are a result of the transcendental character of his philosophy. After all, his transcendentalism amounts to a Vernunftkritik that asks about the limits of reason, and in this sense it exceeds the narrow limits of naïve belief in objective reason. The question of limits, however, leads towards the question of unreason. The distinction between reason and unreason became a life-long concern of Husserl right through his last unfinished work, that is, Die Krisis. In that work, Husserl strongly emphasizes the rational dimension of human life (Hua VI, 5-7). He also argues that the question of reason involves not only fields of cognition, but also practical and axiological dimensions. In this paper, I have focused on the field of cognition and knowledge, and, in doing so, on the question of ,Evidenz.' I have argued that perfect evidence is connected with the concept of objective reason, whereas the question of levels of evidence is associated with the issue of unreason. Husserl's reconsiderations of the problem of the correlation between reason and unreason shows that one element cannot be comprehended without the other. In other words, reason cannot be grasped without considering the question of its many levels and grades. Thus one is justified in speaking of the "antirational constitution of reason" (Nenon, 2009, 194) in Husserl's phenomenology.

Aron Gurwitsch $(1957,396)$ once wrote: "In our day and age it has become fashionable to denounce rationalism as a source of evil and to hold it responsible for the present crisis, both intellectual and moral." More recently, James Hart $(1992,93)$ writes: "We hear from many quarters and over and over again that it is the hybris of reason, logos, rationality, science, intellect, and theoretical understanding that is one of the profound symptoms if not causes of our cultural decay." As a matter of fact, reason is often comprehended as an all-powerful force that dominates reality and excludes everything irrational. Yet from the viewpoint of phenomenology this popular opinion is naïve, because it cannot grasp reason and unreason as correlates. This means, however, that unreason has its sense too only from the perspective of rational investigation, and reason defines itself as a correlate of what is irrational. By binding reason to evidence, and relating unreason to vague cognition, one becomes able to see that the objective view of evidence that conceives it as perfect 
evidence reduces all possible levels and grades of ,Evidenz' to merely one stratum. Thus strong rationalism is naïve. More appropriate, on the other hand, seems to be the moderate rationalism that asks about ,Evidenz' itself. Only in this sense, that is, by understanding what is vague, can one argue that reason breaks the spell of irrationality. At the very end, one can see that this is one of the key insights offered by Husserl's inquiry into phenomenology of reason and of ,Evidenz.'

Acknowledgments. I would like to express my gratitude to the two anonymous reviewers of the journal for their suggestions and comments. I am also grateful to George Heffernan for his priceless help with the language of the manuscript.

\section{REFERENCES}

Adorno, T. W. (1940). Husserl and the Problem of Idealism. The Journal of Philosophy, 37(1), 5-18. Adorno, T. W. (2003). Zur Metakritik der Erkenntnistheorie. Studien über Husserl und die phänomenologischen Antinomien. Frankfurt am Main: Suhrkamp.

Aguirre, A. (1972). Transzendentalphänomenologischer Rationalismus. In U. Claesges \& K. Held (Eds.), Perspektiven transzendentalphänomenologischer Forschung. Für Ludwig Landgrebe zum 70. Geburtstag von seinen Kölner Schülern (102-128). Den Haag: Martinus Nijhoff.

Berghofer, P. (2018a). New Ways to Transcendental Phenomenology: Why Epistemology Must be a Descriptive and Eidetic Study of Consciousness. Horizon. Studies in Phenomenology, 7 (1), 121-136. doi: 10.21638/2226-5260-2018-7-1-121-136

Berghofer, P. (2018b). Why Husserl is a Moderate Foundationalist. Husserl Studies, 34(1), 1-23. doi: 10.1007/s10743-017-9213-4

Berghofer, P. (2018c). Why Husserl's Universal Empiricism is a Moderate Rationalism. Axiomathes, 28(5), 539-563. doi: 10.1007/s10516-018-9388-0

Berghofer, P. (2019). On the Nature and Systematic Role of Evidence: Husserl as a Proponent of Mentalist Evidentialism? European Journal of Philosophy, 27(1), 98-117. doi: 10.1111/ ejop. 12405

Byrne, T. (2017). Surrogates and Empty Intentions: Husserl's "On the Logic of Signs" as the Blueprint for his First Logical Investigation. Husserl Studies, 33(3), 211-227. doi: 10.1007/ s10743-017-9210-7

Crowell, S. G. (2007). Authentic Thinking and Phenomenological Method. In K.-Y. Lau \& J. J. Drummond (Eds.). Husserl's Logical Investigations in the New Century: Western and Chinese Perspectives (119-133). Dordrecht: Springer.

De Boer, T. (1978). The Development of Husserl's Thought (T. Plantinga, Trans.). Boston, MA, London: Martinus Nijhoff.

Dodd, J. (2004). Crisis and Reflection. An Essay on Husserl's "Crisis of the European Sciences". Dordrecht: Kluwer Academic Publishers.

Dreyfus, H. L. (Ed.). (1984). Husserl, Intentionality and Cognitive Science. Cambridge, MA, London: MIT Press.

Drummond, J. (1990). Husserlian Intentionality and Non-Foundational Realism: Noema and Object. Dordrecht, Boston, MA, London: Kluwer Academic Publishers.

Drummond, J. J. (2008). Historical Dictionary of Husserl's Philosophy. Malden, MA: Scarecrow Press. 
Fink, E. (1966). Das Problem der Phänomenologie Edmund Husserls. In. E. Fink, Studien zur Phänomenologie. 1930-1939 (179-223). Den Haag: Martinus Nijhoff.

Fink, E. (1981). The Problem of the Phenomenology of Edmund Husserl (R. M. Harlan, Trans.). In W. McKenna, R. M. Harlan, \& L. E. Winters (Eds.), Apriori and World. European Contribution to Husserlian Phenomenology (21-55). The Hague: Martinus Nijhoff.

Funke, F. (1980). Kritik der Vernunft und ethisches Phänomen. Phänomenologische Forschungen, 9, 33-89.

Gadamer, H.-G. (1963). Die phänomenologische Bewegung. Philosophische Rundschau, 11(1-2), 1-45.

Gallagher, S., \& Zahavi, D. (2008). The Phenomenological Mind. An Introduction to Philosophy of Mind and Cognitive Science. London, New York, NY: Routledge.

Gurwitsch, A. (1957). The Last Work of Edmund Husserl. Philosophy and Phenomenological Research, 17(3), 370-398.

Hart, J. G. (1992). The Entelechy and Authenticity of Objective Spirit: Reflections on Husserliana XXVII. Husserl Studies, 9(2), 91-110. doi: 10.1007/BF00366749

Hartimo, M. (2010). The Development of Mathematics and the Birth of Phenomenology. In M. Hartimo (Ed.), Phenomenology and Mathematics (107-121). Dordrecht: Springer. doi: 10.1007/978-90-481-3729-9_6

Heffernan, G. (1998). Miscellaneous Lucubrations on Husserl's Answer to the Question "was die Evidenz sei": A Contribution to the Phenomenology of Evidence on the Occasion of the Publication of Husserliana Volume XXX. Husserl Studies, 15(1), 1-75. doi: 10.1023/A:1006043225566

Heffernan, G. (2009). On Husserl's Remark that “[s]elbst eine sich als apodiktisch ausgebende Evidenz kann sich als Täuschung enthüllen...” (XVII 164: 32-33): Does the Phenomenological Method Yield Any Epistemic Infallibility? Husserl Studies, 25(1), 15-43. doi: 10.1007/ s10743-008-9051-5

Hohl, H. (1962). Lebenswelt und Geschichte. Grundzüge der Spätphilosophie E. Husserls. Freiburg, München: Karl Alber Verlag.

Holzey, H. (2010). Neo-Kantianism and Phenomenology: The Problem of Intuition. In R. A. Makkreel \& S. Luft (Eds.), Neo-Kantianism in Contemporary Philosophy (25-40). Bloomington, IN: Indiana University Press.

Hopkins, B. C. (2006). Husserl's Psychologism, and Critique of Psychologism, Revisited. Husserl Studies, 22(2), 91-119. doi: 10.1007/s10743-006-9008-5

Hopp, W. (2009). Phenomenology and Fallibility. Husserl Studies, 25(1), 1-14. doi: 10.1007/ s10743-008-9053-3

Hopp, W. (2011). Perception and Knowledge: A Phenomenological Account. Cambridge: Cambridge University Press.

Husserl, E. (1950a). Cartesianische Meditationen und Pariser Vorträge (Hua I). Den Haag: Martinus Nijhoff.

Husserl, E. (1950b). Die Idee der Phänomenologie. Fünf Vorlesungen (Hua II). Den Haag: Martinus Nijhoff.

Husserl, E. (1954). Die Krisis der europäischen Wissenschaften und die transzendentale Phänomenologie. Eine Einleitung in die phänomenologische Philosophie (Hua VI). Den Haag: Martinus Nijhoff.

Husserl, E. (1956). Erste Philosophie (1923/24). Erster Teil. Kritische Ideengeschichte (Hua VII). Den Haag: Martinus Nijhoff.

Husserl, E. (1959). Erste Philosophie (1923/24). Zweiter Teil. Theorie der phänomenologischen Reduktion (Hua VIII). Den Haag: Martinus Nijhoff. 
Husserl, E. (1962). Phänomenologische Psychologie. Vorlesungen Sommersemester 1925 (Hua IX). Den Haag: Martinus Nijhoff.

Husserl, E. (1966). Analysen zur passiven Synthesis. Aus Vorlesungs- und Forschungsmanuskripten 1918-1926 (Hua XI). Den Haag: Martinus Nijhoff.

Husserl, E. (1970). Philosophie der Arithmetik. Mit ergänzenden Texten (1890-1901) (Hua XII). Den Haag: Martinus Nijhoff.

Husserl, E. (1970). The Crisis of European Sciences and Transcendental Phenomenology. An Introduction to Phenomenological Philosophy. Evanston, IL: Northwestern University Press.

Husserl, E. (1974). Formale und transzendentale Logik. Versuch einer Kritik der logischen Vernunft (Hua XVII). Den Haag: Martinus Nijhoff.

Husserl, E. (1975). Logische Untersuchungen. Erster Band. Prolegomena zur Reiner Logik (Hua XVIII). Den Haag: Martinus Nijhoff.

Husserl, E. (1979). Aufsätze und Rezensionen (1890-1910) (Hua XXII). The Hague, Boston, MA, London: Martinus Nijhoff.

Husserl, E. (1983). Studien zur Arithmetik und Geometrie. Texte aus dem Nachlass (1886-1901) (Hua XXI). The Hague, Boston, MA, Lancaster: Martinus Nijhoff.

Husserl, E. (1984a). Einleitung in die Logik und Erkenntnistheorie. Vorlesungen 1906/07 (Hua XXIV). Dordrecht, Boston, MA, Lancaster: Martinus Nijhoff.

Husserl, E. (1984b). Logische Untersuchungen. Zweiter Band. I. Teil. Untersuchungen zur Phänomenologie und Theorie der Erkenntnis (Hua XIX/1). Den Haag: Martinus Nijhoff.

Husserl, E. (1984c). Logische Untersuchungen. Zweiter Band. II. Teil. Untersuchungen zur Phänomenologie und Theorie der Erkenntnis (Hua XIX/2). Den Haag: Martinus Nijhoff.

Husserl, E. (1987). Aufsätze und Vorträge (1911-1921) (Hua XXV). Dordrecht, Boston, Lancaster: Martinus Nijhoff.

Husserl, E. (1988). Vorlesungen über Ethik und Wertlehre 1908-1914 (Hua XXVIII). Dordrecht, Boston, MA, London: Kluwer Academic Publishers.

Husserl, E. (1989). Aufsätze und Vorträge (1922-1937) (Hua XXVII). Dordrecht, Boston, MA, London: Kluwer Academic Publishers.

Husserl, E. (1993). Die Krisis der europäischen Wissenschaften und die transzendentale Phänomenologie. Ergänzungsband. Texte aus dem Nachlass 1934-1937 (Hua XXIX). Dordrecht, Boston, MA, London: Kluwer Academic Publishers.

Husserl, E. (1994a). Briefwechsel. Band III. Die Göttinger Schule. Dordrecht, Boston, MA, London: Kluwer Academic Publishers.

Husserl, E. (1994b). Briefwechsel. Band VII. Wissenschaftlerkorrespondenz. Dordrecht, Boston, MA, London: Kluwer Academic Publishers.

Husserl, E. (1995). Ideen zu einer reinen Phänomenologie und phänomenologischen Philosophie. Erstes Buch. Allgemeine Einführung in die reine Phänomenologie (Hua III/1). Dordrecht, Boston, MA, London: Kluwer Academic Publishers.

Husserl, E. (1996). Logik und allgemeine Wissenschaftstheorie. Vorlesungen 1917/18 mit ergänzenden Texten aus der ersten Fassung von 1910/11 (Hua XXX). Dordrecht, Boston, MA, London: Kluwer Academic Publishers.

Husserl, E. (2001). Allgemeine Erkenntnistheorie. Vorlesung 1902/03. Dordrecht: Kluwer Academic Publishers.

Husserl, E. (2002). Einleitung in die Philosophie. Vorlesungen 1922/23 (Hua XXXV). Dordrecht, Boston, MA, London: Kluwer Academic Publishers.

Husserl, E. (2005). Einführung in die Phänomenologie der Erkenntnis. Vorlesung 1909. Drodrecht: Springer. 
Husserl, E. (2008). Die Lebenswelt. Auslegungen der vorgegebenen Welt und ihrer Konstitution. Texte aus dem Nachlass (1916-1937) (Hua XXXIX). Dordrecht: Springer.

Husserl, E. (2014). Grenzprobleme der Phänomenologie. Analysen des Unbewesstseins und der Instinkte. Metaphysik. Späte Ethik. Texte aus dem Nachlass (1908-1937) (Hua XLII). Dordrecht: Springer.

Ingarden, R. (1975). On the Motives which led Husserl to Transcendental Idealism. The Hague: Martinus Nijhoff.

Janssen, P. (1970). Geschichte und Lebenswelt. Ein Beitrag zur Diskussion von Husserls Spätwerk. Den Haag: Kluwer Academic Publishers.

Landgrebe, L. (1963). Der Weg der Phänomenologie. Das Problem einer ursprünglichen Erfahrung. Gütersloh: Gerd Mohn.

Lembeck, K.-H. (2003). Begründungsphilosophische Perspektiven: Husserl und Natorp über Anschauung. Phänomenologische Forschungen, 97-108.

Lerner, R. R. P. (2004). Husserl versus Neo-Kantianism Revisited: On Skepticism, Foundationalism, and Intuition. The New Yearbook for Phenomenology and Phenomenological Philosophy, 4, 173-208.

Lübbe, H. (1957/1958). Husserl und die europäische Krise. Kant-Studien, 49(1-4), 225-237.

Mall, R. A. (1973). Experience and Reason. The Phenomenology of Husserl and its Relation to Hume's Philosophy. The Hague: Martinus Nijhoff.

Merleau-Ponty, M. (1945). Phénoménologie de la perception. Paris: Gallimard.

Merleau-Ponty, M. (2002). Phenomenology of Perception. London, New York, NY: Routledge.

Mohanty, J. N. (1971). Husserl's Concept of Intentionality. Analecta Husserliana, 1, 100-132.

Mohanty, J. N. (2008). The Philosophy of Edmund Husserl. A Historical Development. New Haven, CT, London: Yale University Press.

Natorp, P. (1917/1918). Husserls 'Ideen zu einer reinen Phänomenologie'. Logos. Internationale Zeitschrift für Philosophie der Kultur, 7, 224-246.

Nenon, T. (2009). Husserls antirationalistische Bestimmung der Vernunft. In M. Pfeifer \& S. Rapic (Eds.), Das Selbst und sein Anderes. Festschrift für Klaus Erich Kaehler (181-194). Freiburg, München: Verlag Karl Alber.

Płotka, W. (2012). Husserlian Phenomenology as Questioning: An Essay on the Transcendental Theory of the Question. Studia Phaenomenologica, 12, 311-330.

Płotka, W. (2016). Knowledge and the Lifeworld: Phenomenological-Transcendental Investigations. In A.-T. Tymieniecka \& P. Trutty-Coohill (Eds.), The Cosmos and the Creative Imagination (167-177). Dordrecht: Springer. doi: 10.1007/978-3-319-21792-5_11

Płotka, W. (2018). Reduction and the Question of Beginnings in Husserl, Fink and Patočka. Human Studies, 41(4), 603-621. doi: 10.1007/s10746-018-09482-3

Rinofner-Kreidl, S. (2003). Mediane Phänomenologie. Subjektivität im Spannungsfeld von Naturalität und Kulturalität. Würzburg: Königshausen \& Neumann.

Scheler, M. (1995). Idealismus-Realismus. In M. Scheler, Späte Schriften (Gesammelte Werke, Bd. 9) (183-241). Bonn: Bouvier Verlag.

Sokolowski, R. (1987). Husserl and Frege. The Journal of Philosophy, 84, 521-528.

Spiegelberg, H. (1994). The Phenomenological Movement. A Historical Introduction. Dordrecht, Boston, MA, London: Kluwer Academic Publishers.

Staiti, A. (2013). The 'Ideen' and Neo-Kantianism. In L. Embree \& T. Nenon (Eds.), Husserl's Ideen (71-90). Dordrecht: Springer. 